\title{
Accelerated Placental Villous Maturation
}

National Cancer Institute

\section{Source}

National Cancer Institute. Accelerated Placental Villous Maturation. NCI Thesaurus. Code C118143.

Placental villous histology not typical of gestational age, with features of more mature villi. 